Mandler, David. "Nopcsa, Baron Franz. 2014. Traveler, Scholar, Politician, Adventurer - A Transylvanian Baron at the Birth of Albanian Independence (ed. and trans. from German Robert Elsie)." Hungarian Cultural Studies. eJournal of the American Hungarian Educators Association, Volume 7 (2014): http://ahea.pitt.edu

DOI: $10.5195 /$ ahea.2014.154

\title{
Nopcsa, Baron Franz. 2014. Traveler, Scholar, Politician, Adventurer - A Transylvanian Baron at the Birth of Albanian Independence (ed. and trans. from German Robert Elsie). Budapest: Central European University Press. 227 pp.
}

\section{Reviewed by David Mandler, Independent Scholar}

Completed circa twenty years after the events therein described, the memoirs of Baron Franz (Ferenc) Nopcsa von Felső-Szilvás (1877-1933), originally written in German and first published in 2001, most resemble an uneven patchwork of largely soporific narrative, consisting of undeveloped character sketches, superficial travel itinerary reports, a lengthy reproduction of Nopcsa's articles in Austrian newspapers on the political situation of 1911 Albania, and boastful allusions to the author's encounters with various members of the Austro-Hungarian elite, all interwoven with a coarse strand of prejudices. It soon becomes clear even to the casual reader that the academically and politically marginalized Nopcsa, by this time deprived of his title and income as Transylvania became part of Romania after World War I, intended to solidify his image with this work not only as an expert on Albania but also as a hyper-masculine master of conflict resolution. In light of Nopcsa's fatally shooting his long-time Albanian secretary (who was also his lover) before committing suicide in 1933, just a year after he completed revisions on his memoirs, the overwhelming effect of the newly translated record of this extraordinary Hungarian nobleman, a geologist and a noted paleontologist with deep ties to Albania, is one of extreme pathos.

In a barely seven-page introduction to his edited selections and translation of Franz Nopcsa's memoirs, Robert Elsie, a prolific Canadian independent scholar of Albanian studies, provides a necessary but rather skeletal account of Nopcsa's biography and significance in geology and paleontology. Much of the book's introduction can also be read on Elsie's website on early photography in Albania, including additional interesting details about both Nopcsa's life and the construction of his memoirs (http://www.albanianphotography.net/nopcsa/). In the introduction, Elsie describes Nopcsa as "one of the most adventuresome travelers and scholars of southeastern Europe in the early decades of the twentieth century" (vii), who is "considered [to be] one of the founders of palaeophysiology" (viii). Born in Deva, now in Western Romania, Nopcsa spent his childhood years in Szacsal (Săcel) on his family's estate until he was sent to Vienna to finish his secondary school education. He gave his first successful lecture on dinosaurs (the remnants of which he found first near Szentpéterfalva in 1895 as Elsie writes on his website but not in the book) at the age of twenty-two at the Academy of Sciences in Vienna (viii). After he obtained a doctorate at the University of Vienna in 1903, Nopcsa visited Ottoman Albania for the first time. He returned to Albania a few years later and established a household in Shkodra until 1914. During his residence in Albania, he became an expert on Albanian culture, and actively agitated for an independent Albania both in speeches and by smuggling in weapons; he even

$($ (c) $)$ EY

ULIS D-Senk 
Mandler, David. "Nopcsa, Baron Franz. 2014. Traveler, Scholar, Politician, Adventurer - A Transylvanian Baron at the Birth of Albanian Independence (ed. and trans. from German Robert Elsie)." Hungarian Cultural Studies. eJournal of the American Hungarian Educators Association, Volume 7 (2014): http://ahea.pitt.edu

DOI: $10.5195 /$ ahea.2014.154

offered himself as a candidate to the Albanian throne in 1913. Elsie counts "at least 54 ...works... related specifically to Albania" (ix) out of the 191 works "primarily in the fields of palaeontology, geology, and Albanian studies" (ibid.) that Nopcsa published throughout his career (Elsie includes a very useful bibliography of Nopcsa's published writings following the memoirs). Having lost his estates at the end of World War I, Nopesa eventually had to find paid employment. He ended up heading and successfully reorganizing the Royal Hungarian Geological Institute from 1925 until he quit in protest in 1928, devoting much of his time to scholarship in Budapest and later in Vienna even as he struggled with increasingly severe bouts of depression. At that period, apparently to help support himself, he also sold his fossil collection to the Natural History Museum in London (ix).

While Nopcsa's completed memoirs begin in 1896 and end in 1917 (with the year 1918 no longer in the archives), Elsie's selection of Nopcsa's memoirs consists of four sections from 1903 to 1914. Elsie does not inform the reader about his methodology and reasons for including or excluding material in his English translation of Nopcsa's memoirs; he does, however, refer to the source material that "consists of 456 typed and partially handwritten pages, which the author went through several times with corrections...in ink of five different colors" (xi). Elsie believes that Nopcsa began to write his memoirs prior to the outbreak of World War I and completed them in 1929, but his estimate of the time of completion of the memoirs is incorrect, since Nopcsa parenthetically mentions a 1932 visit he made to museums in Marseille and Lyon (136). Elsie concludes his introduction by stating that his translation of the memoirs contains "the core sections of the German original, though it excludes the material on [Nopcsa's] early years, his military career in the First World War, and the rather curious episode of his life when he gave up his social position and lived as a Romanian shepherd in the Carpathian mountains" (xii). It would have been quite useful to know why Elise decided to provide an incomplete rendition of the original memoirs, which end on a wistful and melancholic note as Nopcsa speculates about the people he would invite to his own funeral and muses on a world that has forever changed for the worse.

Franz Nopcsa's foremost endeavor in the earlier parts of the book is to establish himself as a masculine force of domination, which he tries to achieve by peppering his narrative with references to his expert handling of guns and successes as a mountain climber. Nopcsa, keenly aware of the way manliness was supposedly measured in Albania a century ago, writes: "In the eyes of the Albanian highlanders, only those who know how to use their rifles are real men" (35). It does not take long for Nopcsa to show that not only did he know how to use his rifle, but he was also involved in (mostly failed) attempts at smuggling weapons into Albania. His attempts at constructing his masculinity though the carriage of firearms result, at times, in unintended hilarity on the part of the reader. Nopcsa offers such useful advice as this: "If you go to the Kelmendi territory, you may want to have a scope on your hunting rifle and thick rubber soled shoes..." For those wondering why, he explains: "It will raise one's prestige among the locals enormously" (35). While one's prestige may be raised, the thick rubber inlay of the boots Nopcsa wears during another mountain climbing expedition falls apart from the sole, threatening the seemingly autonomous traveler of sufficiently high prestige with destruction. Only the intervention of the "wild and savage Albanians" saves the stranded Nopcsa as they quickly repair his shoes; Nopcsa then observes that "the sons of the mountains were as good with a needle and 
Mandler, David. "Nopcsa, Baron Franz. 2014. Traveler, Scholar, Politician, Adventurer - A Transylvanian Baron at the Birth of Albanian Independence (ed. and trans. from German Robert Elsie)." Hungarian Cultural Studies. eJournal of the American Hungarian Educators Association, Volume 7 (2014): http://ahea.pitt.edu

DOI: $10.5195 /$ ahea.2014.154

thread as they were with a rifle" (40). Rather than gesturing at a broadened definition of the masculinity of these "wild and savage Albanians," Nopcsa's marrying the needle to the rifle as specific markers of gender roles in fact feminizes these Albanians. While the author mentions the locals who helped him in his expeditions, the tone he uses to describe his conquests of Nature is one of forced masculine autonomy; for example, this conquering man becomes angry when he realizes that the mountain he just climbed is not the highest in the region (38). Thus, Nopcsa implies that it is not the experience itself that is significant but rather how it frames his personality in terms of measurable achievement.

Another recurrent aspect of Nopcsa's self-representation is the persistence with which he describes personal conflicts he successfully resolves and political conflicts he intends to but, more often than not, fails to resolve. An episode that showcases Nopcsa's ingenuity and loyalty to his Albanian acquaintances and friends involves a certain Mustafa Lita, "one of the most dastardly robbers of Dibra in all of Turkey at the time" as Nopcsa asserts (47). A few days into his stay with Lita as his guest, Nopcsa is informed that he, along with his secretary Bajazid, are, in fact, Lita's prisoners. Further solidifying his hyper-masculine image, Nopcsa writes, "my first impulse was to shoot Mustafa Lita and put an end to the nonsense, but I thought better" (48). As a guest-turned-prisoner of this "dastardly" robber, Nopcsa eventually proposes an elaborate scheme to resolve a standoff that allows for Mustafa Lita to save face. In another episode, Nopcsa handles a dispute involving a runaway bride who pretends to be sick while staying at Nopcsa's house as his guest. Since Nopcsa bears responsibility towards both the woman now under his protection and the fiancé, who is the brother of his blood brother, he proposes a solution in keeping with both church law and the Albanian customary law known as Kanun. Unfortunately, Nopcsa's repetitious pattern involving episodes of outsmarting Turkish and Austrian officials, intervening in blood feuds, and offering mutually acceptable solutions to kidnappers, thieves or even murderers soon turns tedious.

While the sense of general tedium is not lessened by the author's dense descriptions of difficult-to-follow and rather archaic political intrigues among the Turkish, the AustroHungarians, the Italians, the Muslims and a number of Catholic priests in Albania in the 1910s, some tidbits about important figures in history -- such as Archduke Franz Ferdinand -- may interest more readers. Surprised that Franz Ferdinand who was assumed to have hated Hungarians is receptive to a Hungarian, or more precisely to Nopcsa's private reports on Albania, the author observes in a characteristically casual and rather callous tone that the Archduke "only hated the Hungarian Jews" (96). He adds, "I received confirmation of this from my uncle, the anti-Semitic Count Robert Zselensky, who was also a follower of Franz Ferdinand" (97). Nopcsa does not hide his strong, class-based anti-Semitism either, especially when it comes to Jews (or people he wrongly assumes to be Jews) elevated to any rank of nobility. He retells with relish a popular anecdotal account of the Jewish grain merchant whose grandson, Count Alois Lexa von Aehrenthal (1854-1912), the minister of foreign affairs mostly remembered for engineering the annexation of the Balkans. The spurious anecdote, in Nopcsa's eyes, serves to denigrate Aehrenthal, who was hostile to Nopcsa's ideas regarding Albania. Valuable to the historian of the Habsburg and the Ottoman empires, details involving Monsignor Sereggi's machinations and other mundane details only serve to frustrate readers unfamiliar with the actors on the political scene in the 1910s Balkan politics. The insertion of more than twenty-five pages of articles 
Mandler, David. "Nopcsa, Baron Franz. 2014. Traveler, Scholar, Politician, Adventurer - A Transylvanian Baron at the Birth of Albanian Independence (ed. and trans. from German Robert Elsie)." Hungarian Cultural Studies. eJournal of the American Hungarian Educators Association, Volume 7 (2014): http://ahea.pitt.edu

DOI: $10.5195 /$ ahea.2014.154

Nopcsa published in various Austrian and English newspapers in 1911 on the subject of AustriaHungary's policy in the Balkans, in which Nopcsa generally rails against Austrian foreign policy, makes easier the job of researchers looking for information on the political situation in the Balkans prior to World War I; it does nothing, however, to help the reader gather a sense of coherence in the narrative.

The reader also looks in vain for the man Franz Nopcsa in the sections that Robert Elise decided to translate from the memoirs (although it is doubtful that Elise would have excluded such valuable material if it did exist in the original). Nopcsa, making use of voluminous diary entries as his source material, provides only snippets of his personal life. Debilitating illnesses such as "an attack of the nervous system... [causing] terrible cramps in [his] stomach and guts" (70) often interrupt his otherwise dizzying travels from his home in Transylvania to Vienna, Mitrovice, Skopje, Shkodra, Paris, London and countless other European cities, to the point that it seems that only his illnesses constitute his inner weakness. Eager to construct a hypermasculine image, Nopcsa omits any references to his homosexual relationship with his Albanian secretary, Bajazid Elmaz Doda (1888-1933), whom as Robert Elise states in his introduction he met in 1906 and shot to death in 1933. This long-term companion of Nopcsa's emerges only periodically in the narrative as his informer on local events, fellow traveler, assistant, and domestic servant. Halfway into the memoir, Nopcsa identifies Bajazid's significance stating that Bajazid was "taking care of [Nopcsa's] daily needs [while on a visit in London], such as strawberry jam, etc." (94). Nopcsa condenses all the unnamed acts of "taking care of [his] daily needs" into a painfully absurd function of obtaining a mundane food item, to which he only adds the short "etc." at the end of the sentence. If only that "etc." could speak.

Though deliberately and systematically omitting any direct allusion to his sexuality, Nopcsa does occasionally note his male-centered world: he has only male servants while living in Albania and, when staying overnight on a Muslim farmer's house in Tuzla on his way to Zagreb, he notices the farmer's "several attractive sons from eighteen to twenty-four years of age" (91). In one of the few veiled allusions to his sexual interests, Nopcsa writes that "[he] was in agony" (92) as he visited the family of the deceased Louis Draškovic; but it is Robert Elise, in the introduction, who notes that Louis Draškovic (1879-1909) was Nopcsa's "early love" (xi). Nopcsa receives from Draškovic's family his papers, which he is asked to edit and publish, along with one of the deceased's hats, which "he often wore" (92), but not a word is written about Nopcsa's emotional response to this encounter. Clearly, Nopcsa's generally detached and impersonal tone does a great disservice to an otherwise fascinating life story.

The latter parts of the book describe Nopcsa's gradual realization of how the rough code of honor he knew in Albania, just as other aspects of the world he described and which contemporary readers may only begin to conceive of, is slipping away from him, or "has vanished" (203).With disorienting speed, he then describes his earlier and ultimate political and military activities involving Albania, which ended in failure (naturally, according to him, not because of his own shortcomings). He bewails the passing of an era in which, as he writes, "the noble savages I loved, who clung unswervingly to their code of honor -- a code that did not correspond at all to ours -- were gone, and in their place, with very few exceptions, were men who were greedy for money, timid and apprehensive, and thoroughly unreliable" (204). He even orders that when he dies, eleven of his Albanian acquaintances that he lists by name should be 
Mandler, David. "Nopcsa, Baron Franz. 2014. Traveler, Scholar, Politician, Adventurer - A Transylvanian Baron at the Birth of Albanian Independence (ed. and trans. from German Robert Elsie)." Hungarian Cultural Studies. eJournal of the American Hungarian Educators Association, Volume 7 (2014): http://ahea.pitt.edu

DOI: $10.5195 /$ ahea.2014.154

invited, so that they know that he "had been faithful to them and remembered them right to the end" (203). It is only towards the end of the memoirs -- as selected by the editor and translator Elsie -- that a more vulnerable, and therefore more sympathetic human being begins to take shape in the narrative.

It is a pity that Franz Nopcsa, for a variety of reasons that scholars in gender studies and experts on the cultural milieu of the early twentieth century Habsburg Empire would all be happy to explore, was not able to describe more parts of his world in a more organic, coherent and sincere manner. The result of such an endeavor might have been far more useful for scholars and interested readers today. Yet, as partial and obscure as the Nopcsa memoirs may be, they are still worth reading as a document that commemorates a long gone era with its figures, colors and landscapes. 